\title{
Analysis of Management of Village Fund Allocation (ADD) in Pohuwato Regency
}

\author{
Iskandar Ibrahim \\ Jurusan Ilmu Pemerintahan, Fakultas Ilmu Sosial dan Ilmu Politik \\ Universitas Ichsan Gorontalo \\ Email: iskandaribrahim64@gmail.com
}

(Received: March-2019; revised: May-2019; published: June -2019)

\begin{abstract}
ABSTRAK
The purpose of the study was to find out and explain the process of managing the Village Fund Allocation (ADD) in South Marisa Village, Marisa District, Pohuwato Regency and what factors influenced the management of Village Fund Allocation (ADD) in Marisa Selatan Village, Marisa District, Pohuwato District. The method in this study is descriptive with a qualitative approach. Descriptive form is a form of research that focuses on the actual problems or phenomena at the time of the research and describes the facts about the problem being investigated as followed by accurate interruptions. The informants in this study were, the village head of South Sumatra, the village secretary, the village treasurer, the head of the BPD, the head of the hamlet and the community leaders of South Sumatra. The results of the study show that the ADD Management Process includes Planning, Implementation, Administration, Reporting and Accountability. ADD management carried out by the Government of South Marisa Village, Marisa Subdistrict, Pohuwato Regency has followed the rules of technical guidelines that have been regulated in the legislation. but the process is still not optimal. This can be seen from the reporting process and the liability that has been delayed. For the Realization Reporting Process, the use of ADD is not yet in accordance with the predetermined schedule, causing delays in disbursing the Fund for the next stage. Likewise with the Pertanganggung answer for the use of ADD so that the community cannot evaluate the work of the village government and accountability to the regional government that is not implemented in a timely manner.
\end{abstract}

Keywords: Management; Village Fund Allocation; Village.

\section{INTRODUCTION}

The Law of the Republic of Indonesia Number 6 of 2014 concerning Villages is a product of the reform era which became the initial form of village independence in the administration of Government and in the management of Village Finance. Allocation of village funds (ADD) is one form of financial relations between levels of Government, namely the financial relationship between District Government and Village Government (Daraba, 2015, 2017). In order to form an appropriate financial relationship, an understanding of the authority of the village government is needed. This means that the government budget given to Desa Desa is fully related to development facilities and village empowerment as one of the institutions that are contributing to the government format. The funds must be used and allocated as appropriate according to the applicable laws and regulations set by the Indonesian government so that the Village Fund Allocation (ADD) is able to improve Village Development, Community 


\author{
26 Jurnal Administrare: Jurnal Pemikiran Ilmiah dan Pendidikan Administrasi Perkantoran \\ Volume 6 Number 1 January-June 2019. Pages 25-34
}

Participation in Empowering and Implementing such assistance in the future (Bangun, 2009; Gani, 2015; Kalesaran, 2015; Nawir, Maulana, Nuryamin, \& Husain, n.d.; Rengifurwarin, Akib, Jasruddin, \& Salam, 2018; Saggaf, Akib, Salam, Baharuddin, \& Kasmita, 2018; Saggaf, Aras, et al., 2018; Salam, 2015).

The legal basis for allocating Balancing Funds to the Village is in accordance with the mandate of Law Number 6 Year 2014 Article 72 paragraph (4), if this is not done then strict sanctions are stated in Article 72 paragraph (6), where the Government can delay and / or deduction of equalization Fund allocation after deducting Special Allocation Funds. In Government Regulation (PP) Number 43 of 2014 which has been revised to PP No. 47 of 2015 concerning implementing regulations of Law Number 6 of 2014 concerning Villages Article 96 paragraph (3) ADD allocations are channeled in consideration of population, poverty rate, area and the level of geographical difficulty. In relation to the provision of Village fund budget allocations in Pohuwato District, the District Government has provided technical instructions regarding the distribution process and the total budget ceiling for each village through Pohuwato Regent Regulation Number 49 of 2016 concerning Technical Guidelines for Village Fund Allocation.

The implementation of the Village Fund Allocation (ADD) in Pohuwato Regency is based on the reality that as a pillar of regional autonomy, villages increasingly need balanced funding to carry out more concrete roles in regional development. The Pohuwato District Government hopes that with the allocation of funds to the Village, community-based participatory planning will be more sustainable, because the community can be directly involved in making planning documents in their villages and participating in the realization.

Based on the initial research that the author did, obtained information from the Community illustrating that the Village Fund Allocation Management (ADD) in Marisa Selatan Village, Marisa Subdistrict, Pohuwato Regency still has many problems, both in the fields of planning, implementation, administration, reporting, and village financial accountability ( ADD). At the stage of ADD user planning, it is more likely that the program will be carried out by the Village Head so that at the time of the Development Plan Deliberation the community leaders who present are only limited to hearing.

In the discussion phase of the plan to use the Village Fund Allocation (ADD) presented only certain people while the results of the discussion on the plan to use the Village Fund Allocation (ADD) were not informed to the public in general so that the community did not even know that the Village received large financial assistance from Local governments through the APBD have implications for the participation of the people who tend to be apathetic in the activities carried out by the Village Fund Allocation (ADD) manager.

\title{
METHOD
}

This research was conducted in Marisa Selatan Village, Marisa District, Pohuwato District, Gorontalo Province. The type of research used is descriptive with a qualitative approach that is a form of research that focuses on the actual problems or phenomena at the time of the research and describes the facts about the problem being investigated as followed by accurate interruptions. (Nawawi, 2005: 64). The technique of determining informants in this study was purposive sampling, namely determining the informant as a source of data based on certain considerations (Sugiono, 2005: 53). The informants in this study were 15 people 
consisting of: South Marisa Village Chief, Secretary of South Marisa Village, Treasurer of South Marisa Village, Chairperson of South Marisa BPD, Hamlet Heads and community leaders of South Marisa Village. As for some data collection techniques in this study, namely: 1) Observation, namely the data retrieval process in research where researchers or observers by observing conditions relating to the object of research, 2) Interview, is a conversation process with a specific purpose. This conversation was conducted by two parties in the form of question and answer to a number of informants to obtain information and ideas that are closely related to this research, and 3) Library research, namely by reading books, documents, laws, and information media others related to the government's role in the village of South Marisa, Marisa District, Pohuwato Regency. Data analysis is an activity of grouping, making a sequence, increasing data so that it is easy to make a description. In accordance with the research method, the data analysis technique used in this study uses qualitative techniques. According to Farid (1997: 152) that qualitative analysis is an analysis of the data obtained based on the reasoning ability of researchers in connecting facts, data and information.

\section{RESULT AND DISCUSSION}

Village Fund Allocation (ADD) is the Allocation of Funds to Villages with the calculation of the Balancing Fund received by the Regency by $10 \%$ after deducting the Special Allocation Fund (DAK). Management of ADD includes the Process of Planning, Implementation, Administration, Reporting and Accountability. All of these processes were carried out by the Village Government accompanied by the District Facilitation Team. Not only that, the community also participates in ADD supervision.

Before Planning a Village Fund Allocation (ADD), first determine the ADD amount. Determining the amount of ADD funds that will be received by each village in Pohuwato Regency is determined based on Minimum ADD calculation and Proportional ADD. Minimum ADD is a fund allocated for ADD which is shared equally among all villages in Pohuwato District. Whereas Proportional ADD is determined based on the village weight value determined and formulated by the District Facilitation Team and stipulated in the Regent's Decree.

Especially for the Proportional Village Fund Allocation (ADDP), it is calculated by taking into account the population, poverty rate, area size, and geographical difficulty index of each village in Pohuwato Regency. Minimum Village Fund Allocation of 60\% and Proportional Village Fund allocation of 40\%. Proporsioanl Village Fund Allocation is calculated based on population data, poverty rate, area size, and geographical difficulty index originating from the authorized ministries and / or institutions that administer Government affairs in the Statistics field.

\section{Planning}

Planning is a process of determining something that you want to achieve in the future and determine the stages needed to achieve it. This becomes important because planning is one indicator of the success of an activity. In village financial planning, a strategic stage plan is needed. One that can be planned in this case is how to best allocate village funds. At the planning stage the use of ADD is preceded by a Village Development Planning Meeting (Musrenbang village) involving BPD, LPMD, and other community leaders, Village Fund 


\section{Jurnal Administrare: Jurnal Pemikiran Ilmiah dan Pendidikan Administrasi Perkantoran Volume 6 Number 1 January-June 2019. Pages 25-34}

Allocation (ADD) planning is carried out by capturing the aspirations and needs of the community through village meetings. Village Fund Allocation (ADD) is one of the village income whose use is integrated with the Village Budget (APBDes). Therefore, the planning program and activities are prepared through the Village Development Planning Consultative Forum.

In the Village Fund Allocation Planning (ADD) Process begins with a village meeting, To formulate a plan the Activity must involve the participation of all components in the Village, both community institutions and the general public through a Village level discussion forum. This was explained by the Bakia Hamlet Chief who said:

"Usually 1 or 2 months before our Village Musrenbang, the hamlet head holds a hamlet meeting with the community and community leaders, then all the meetings after that the cadet and the village head together with the village apparatus hold a small meeting and all the activities that are to be initiated in the survey" ( Interview Results, December 2018).

Carrying out the Village Government Musrenbang Village to conduct a Pre-Meeting to produce an activity program that wants to be implemented This is similar to that delivered by Kadus Melati that:

"When the Musrenbang was implemented, Kadus Village held a village meeting and then held a meeting with the village head and village officials to do the Apbdes planning, later when the musrembangdes was offered to the community what they wanted to do." (Interview Results December 2018).

Convoluted with community involvement in general at the Musrenbang village, did the people of Marisa Selatan Village know that the Village Government had received a source of Funds from the District Government namely Alokasi Dana Desa (ADD) One informant from the Village Toolkit said that "All the communities in the Village South Marisa already knows, if the Village Government gets ADD Funds "(Interview Results, December 2018).

After the Village Government made the Format of the Village RKP, the implementing team of the ADD activity prepared a format for the Budget Plan (RAB), explained by one of the South Sumatra village officials that:

"We are compiling a Cost Budget Plan (RAB) based on Market price data where we discuss how much of the budget used for development, for example the construction of the Tani road, requires a lot of budget" (Interview Results, December 2018).

The Village Musrenbang process is led by the Head of the Village and is attended by the Sub-District Head. In the Musrenbang process, all community needs are discussed, both those that have been previously known and those that have just been delivered by the community. This is based on the results of an interview with the secretary of Desa Marisa Selatan, who said:

"At the time of the Village Musrenbang, led by the Village Head and attended by the subdistrict head, the village head leader of the Village Musrenbang, at that time was asked what the community would propose from each hamlet to be proposed in the sub-district" (Interview results, December 2018). 
The results of interviews and direct observations that have been made, that planning the use of ADD in Marisa Selatan Village, Marisa Subdistrict, Pohuwato District has been carried out in accordance with applicable regulations. This can be seen by the suitability between the planning carried out with the preparation of activity plans which are regulated in the Regulations of Regent Pohuwato Number 2 of 2016 concerning Technical Guidelines for Village Fund Allocation.

\section{Implementation}

Implementation is an action or implementation of a plan that has been prepared carefully and in detail, implementation is usually carried out after the plan has been deemed ready. In implementing the assistance program to the Village Government, every year the Regent of Pohuwato issues a letter governing the implementation of a program that can assist the Village Devices. In order to follow up the Pohuwato Regent Decree, Pohuwatp Regent Regulation number 2 was issued concerning Technical Guidelines on Aloksi Desa Funds which were distributed throughout the villages in Pohuwato Regency. The Technical Guidelines are intended as guidelines for the Village Toolkit.

ADD Implementation The Village Head acts as the person in charge of managing activities originating from ADD. This was confirmed by the village head of Marisa Selatan:

"I, as the person in charge only for the TPK ADD (Team for the implementation of the activities) already in the form, for the Village Implementation Team of the village level 3 people consisting of Village Devices, LPMD, and the community" (Interview December 2018)

While the interview was conducted with the community to find out the accuracy of the use of ADD, the community was an informant. The implementation of ADD use carried out by the South Marisa Village Government was criticized by one of the communities in Bakia Hamlet who said that:

"In terms of the Musrenbang Planning Village in South Marisa Village, in my opinion, it is only a formality because everything that has been done has been agreed upon in the village musrenbang, so those who know maybe only certain communities. on that "(Interview Result, December 2018).

Based on the results of the interviews conducted, on the other hand the South Marisa Village Government also received a positive response in the Implementation of the Use of ADD, especially in implementing Development. In carrying out development, the Village Head of South Marisa always participates in monitoring the development process. This was expressed by the public as an informant saying that "Usually if there is development carried out, the Village Head will immediately help and always monitor every development process" (Interview Results December 2018).

Based on the observations and findings of the researchers, it was found that the Use of Village Fund Allocation in South Marisa Village, it was seen that the recording of ADD use had been done well. The use of ADD in the field of government operations and in the field of implementation of village development has been well detailed. Allocation of use has been in accordance with existing regulations.

\section{Administration}




\section{Jurnal Administrare: Jurnal Pemikiran Ilmiah dan Pendidikan Administrasi Perkantoran Volume 6 Number 1 January-June 2019. Pages 25-34}

Village Finance Administration is all financial activities carried out by the village government, namely the Village Treasurer consisting of Administration of receipt and administration of expenses and reporting of accountability to interested parties. The Village Head holds the highest authority in managing village finance because of his position as head of government at the Village level. In its implementation, the village head is assisted by the Village Financial Management Technical Officer (PTPKD) who is a village apparatus appointed by the village head, PTPKD or Village Financial Management Technical Implementer who assists the Village Head in implementing village financial management.

The Village Treasurer must administer all receipts, deposits, payments, administration, which is his responsibility and close the book at the end of the month in an orderly manner. This is in accordance with the results of interviews with the Head of South Marisa Village, stating that:

"Every Month the Village Treasurer must organize Administration of all receipts, deposits, payments, administration, which is his responsibility and close the book at the end of the month in an orderly manner and Report the Village Financial Conditions" (Interview Results, December 2018).

In addition to the administration stages set, the Village Treasurer must record all transactions in the form of receipts and expenses. The Village Treasurer systematically records the financial transactions that occur, related to the statement, in a separate place the interview was conducted with the Treasurer of the South Marisa Village, saying that:

"When spending cash in the form of shopping to carry out operational activities of the Village and Village programs, we must keep evidence of financial transactions, both cash in and cash out, then record them into the general cash book, tax assistant cash book and bank book later. the village closes every month on the general cash book, tax assistant cash book and bank book, as an accountability report to the village head ". (Interview Results, December 2018).

This is in accordance with what was explained by the Village Head, South Marisa that the Village Treasurer must record all expenditure and receipt of Village Finance. Say:

"In carrying out the expenditure and receipt of the Treasury's Finance, the Treasurer is obliged to record everything in the book Kas and the village treasurer has implemented it according to the existing rules" (Interview Results December 2018).

Based on the results of the Interview, in carrying out the Administration carried out by the South Marisa Village Government in this case the Village Financial Management Task Force (PTPKD) is in accordance with the Regulations on Village Financial Management and that with the Administration conducted by the Village Treasurer in the form of General Cash Book, The Cash Book, Tax Assistant and Bank Book greatly facilitate the BPD and the public to find out whether or not there is a diversion from the huge amount of funds held or managed by the Village Government. 


\section{Reporting}

Forms of Reporting on activities in the APBDesa have two Reporting stages. First, periodic reports, namely reports on the implementation of the use of ADD funds that are made routinely every semester and / or 6 months according to the disbursement stage and the accountability that contains the realization of ADD and ADD receipts. Second, the final report on the use of ADD covers the implementation and absorption of funds, problems faced and recommendations for the completion of the final use of ADD. Both of these reports were made by the Village Head, Village Secretary and Village Treasurer.

The application of the reporting process specified in the Regents Regulations, the authors conducted a study of the reporting process carried out by the village government in Desa Marisa Selatan in implementing Village Fund Allocation (ADD) reporting, reporting its use carried out in two stages, namely the first semester and semester two. explained by the secretary of Desa Marisa Selatan, who stated that:

"For the Management of ADD there are already rules. Usually we are guided by Pohuwato Regent's Regulation number 2 concerning Technical Guidelines for Village Fund Allocation and Perbup Number 56 of 2017 concerning Management of Village Funds. Reporting on the use of ADD is reported in two stages, namely the first semester, no later than the end of July and the second semester at the latest in January" (Interview, December 2018).

Based on the results of the interview, the first phase of the report, which is a periodic report, was held in January and submitted no later than the end of June to the PMD Office of Pohuwato Regency and BKAD to disburse funds. Furthermore, the final report will be held in August and submitted no later than January. However, before being received by PMD and BKAD, the Report was verified by the District Facilitation Team.

The reporting poses for the use of ADD can be summarized briefly in table 1 by briefly explaining the analysis of the process and parties involved in making it.

Table 1.

Results of Analysis on Reporting of Use of ADD in South Marisa Village, Marisa District

\begin{tabular}{|c|c|c|}
\hline Jenis Laporan & Proses & Analisis \\
\hline $\begin{array}{l}\text { 1. Periodic Report } \\
\text { 2. Final report }\end{array}$ & Village level report & $\begin{array}{l}\text { The report on the realization of the use of } \\
\text { funds financed by ADD was carried out in } \\
\text { stages by the village head to the TIM sub- } \\
\text { district facilitator team. }\end{array}$ \\
\hline $\begin{array}{l}\text { - Implementation } \\
\text { - Fund Absorption } \\
\text { - Problems } \\
\text { encountered }\end{array}$ & $\begin{array}{l}\text { Laporan ke Bupati cq. } \\
\text { Dinas PMD untuk di } \\
\text { Verifikasi }\end{array}$ & $\begin{array}{l}\text { The documents needed in the process of } \\
\text { disbursing funds must first be verified by } \\
\text { the Team from BPMDK because the task of } \\
\text { the PMD Service is to provide guidance to } \\
\text { the Village. }\end{array}$ \\
\hline
\end{tabular}




\section{Jurnal Administrare: Jurnal Pemikiran Ilmiah dan Pendidikan Administrasi Perkantoran Volume 6 Number 1 January-June 2019. Pages 25-34}

\begin{tabular}{|l|l|}
\hline Recommended verification & $\begin{array}{l}\text { The required documents are appropriate, so } \\
\text { the recommendations for the verification } \\
\text { results are brought to BKAD to do the } \\
\text { disbursement. }\end{array}$ \\
\hline Disbursement of funds & $\begin{array}{l}\text { The process of submitting reports on the } \\
\text { use of ADD funds must be timely, but the } \\
\text { Marisa Selatan Village government does } \\
\text { not carry out reporting on time or in } \\
\text { accordance with existing regulations } \\
\text { because those who know how to make it } \\
\text { have been transferred to the sub-district } \\
\text { office and replaced by the new Village } \\
\text { secretary. }\end{array}$ \\
\hline
\end{tabular}

Source: Primary Data Analysis, 2018

Village Fund Allocation Reporting (ADD), ie Periodic Reports and Final Reports submitted by the Village Head to the Bupati for verified BPKD and obtaining disbursement recommendations from the BPMDK must be accompanied by several attachments.

"In carrying out the Reporting, there are two stages, if the first stage has been made SPJ then the second phase of disbursement is carried out and not absolute per six months as long as the first phase of funds is disbursed and the realization report can be withdrawn" (Interview Results December 2018).

Further said by the secretary of Desa Marisa Selatan when interviewed, it was said that:

"ADD reports are made separately, because the APBdes in the APBdeskan cover all funding sources, ADD, Village Funds, all of the Tax Results are covered in the APBDES, how many opinions are 1 year. later the reporter on the realization of ADD, there is also a separate Village Fund "(Interview Results December 2018).

On the other hand the author also conducted an interview with one of the Village Devices in South Marisa Village. One informant also explained that:

"The ADD report has not been completed because the village secretary is busy with other matters and we have received a warning letter from Pohuwato's PMD Service because it hasn't deposited in the office" (Interview Result, December 2018).

From the results of the interview above, the authors conclude that in the reporting process in the management of the Village Fund Aloksi (ADD) by the Marisa Selatan Village Government to the PMD Office of Pohuwato Regency it is still not in accordance with established regulations where the village government has not been able to report activities in accordance with determined It can be seen from the completion of the Phase II Realization Report. 


\section{Responsibility}

Village Fund Allocation (ADD) Accountability is integrated with the APBDesa Accountability, so that the responsibility is the accountability of the APB village. The accountability is made in the form of a Village Government Implementation Report (LPPD) at the end of each year and the form of the composition of the report on the implementation of the Village Government refers to Regent Regulation number 56 of 2017 concerning Management of Village Funds.

Making the accountability report conducted by the village government, especially the village secretary, chose to use the services of a third party, because the secretary of the village of Marisa Selatan was classified as a new secretary and did not know the process of making LPPD. the third party in question in Desa Marisa Selatan is the old Village Secretary and now serves as Chair of the LPMD. This is in accordance with what was stated by Secretary of South Marisa, stating that:

"In the preparation of the accountability report, we usually prefer to use the services of third parties, so because we have not been able to usually rent services, because I was just appointed to be the secretary of the South Sumatra village, so there is no experience, especially the ADD technical management instructions every year, to 2018 will change again. In the LPPD, they usually ask for assistance from the old Secretary because the old secretariat knows more about it. " (Interview Results December 2018).

The technicality of making the Accountability Report has been regulated in Regent Pohuwato's Regulation Number 56 of 2017 concerning Village Financial Management. Making this Report of Accountability is intended so that every activity carried out by the Village Government is based on established rules and does not deviate. This is also a manifestation of Village Government transparency to the community. However, the reality that occurred in Desa Marisa Selatan was that the accountability report activities were not planned and implemented properly. This can be seen from the delay in making the accountability report.

\section{CONCLUSION}

The ADD Management Process includes Planning, Implementation, Administration, Reporting and Accountability. The ADD management carried out by the South Marisa Village Government in Marisa District, Pohuwato District has followed the rules of technical guidelines that have been regulated in legislation. but the process is still not optimal. This can be seen from the reporting process and the liability that has been delayed. For the Realization Reporting Process, the use of ADD is not yet in accordance with the predetermined schedule, causing delays in disbursing the Fund for the next stage. Likewise with the responsibility for the use of $\mathrm{ADD}$ so that the community cannot evaluate the work of the village government and accountability to the regional government that is not implemented in a timely manner.

\section{REFERENCES}

Bangun, A. (2009). Pengaruh partisipasi dalam penyusunan anggaran, kejelasan sasaran anggaran dan struktur desentralisasi terhadap kinerja manajerial SKPD dengan 


\section{Jurnal Administrare: Jurnal Pemikiran Ilmiah dan Pendidikan Administrasi Perkantoran}

Volume 6 Number 1 January-June 2019. Pages 25-34

pengawasan internal sebagai variabel pemoderasi (studi kasus pada pemerintah Kabupaten Deli Serdang).

Daraba, D. (2015). Penerapan Prinsip Pelayanan Administrasi Pada Kantor Desa Panciro Kecamatan Bajeng Kabupaten Gowa, Indonesia. Jurnal Office, 1(2), 185-191.

Daraba, D. (2017). Pengaruh Program Dana Desa terhadap Tingkat Partisipasi Masyarakat di Kecamatan Galesong Utara Kabupaten Takalar. Sosiohumaniora, 19(1).

Gani, F. S. (2015). Tahapan Partisipasi Masyarakat Dalam Program Pembangunan Infrastruktur Perdesaan (PPIP) Di Desa Dungaliyo Kecamatan Dungaliyo Kabupaten Gorontalo. Jurnal Ilmiah Ilmu Administrasi Publik, 5(1), 9-19.

Kalesaran, F. (2015). Partisipasi dalam Program Nasional Pemberdayaan Masyarakat Mandiri Perkotaan Kelurahan Taas Kota Manado. Jurnal Ilmiah Society, 1(15), 56-73.

Nawir, R., Maulana, R., Nuryamin, M., \& Husain, T. (n.d.). Implementation Program of Poor Rice Copyright.

Rengifurwarin, Z. A., Akib, A. H., Jasruddin, U. N. M., \& Salam, R. (2018). Snapshot of Public Service Quality in The Center For Integrated Business Service (CIBS), Cooperative Micro Small and Medium Enterprises (CMSME), Maluku Province, Indonesia. Journal of Entrepreneurship Education, 21(3).

Saggaf, M. S., Akib, H., Salam, R., Baharuddin, A., \& Kasmita, M. (2018). The Quality Analysis Of Academic Services.

Saggaf, M. S., Aras, M., Akib, H., Salam, R., Baharuddin, A., \& Kasmita, M. (2018). The Quality Analysis of Academic Services Based on Importance Performance Analysis (IPA).

Salam, R. (2015). Penerapan Fungsi Administrasi Perkantoran Modern berbasis Daya Saing Organisasi dalam menyongsong MEA 2015. SEMINAR NASIONAL "Revolusi Mental Dan Kemandirian Bangsa Melalui Pendidikan Ilmu-Ilmu Sosial Dalam Menghadapi MEA 2015” Himpunan Sarjana Pendidikan Ilmu-Ilmu Sosial Indonesia, 1, 186-190. 